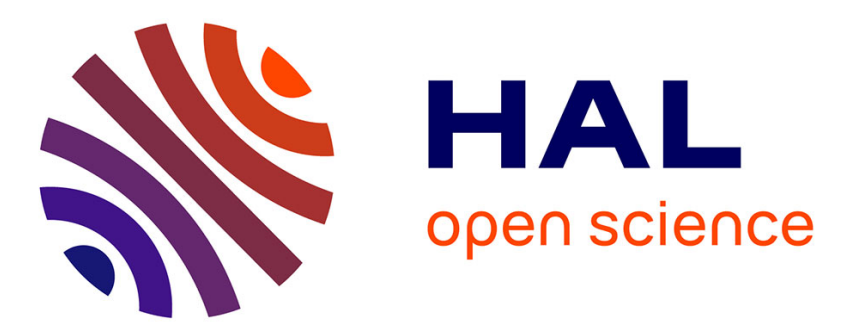

\title{
Lewis acid- and/or Lewis base-catalyzed [3+2] cycloaddition reaction: synthesis of pyrazoles and pyrazolines
}

Palakodety Radha Krishna, Empati Raja Sekhar

\section{- To cite this version:}

Palakodety Radha Krishna, Empati Raja Sekhar. Lewis acid- and/or Lewis base-catalyzed [3+2] cycloaddition reaction: synthesis of pyrazoles and pyrazolines. Tetrahedron Letters, 2008, 49 (48), pp.6733-6936. 10.1016/j.tetlet.2008.09.037 . hal-00783713

\section{HAL Id: hal-00783713 https://hal.science/hal-00783713}

Submitted on 4 Feb 2013

HAL is a multi-disciplinary open access archive for the deposit and dissemination of scientific research documents, whether they are published or not. The documents may come from teaching and research institutions in France or abroad, or from public or private research centers.
L'archive ouverte pluridisciplinaire HAL, est destinée au dépôt et à la diffusion de documents scientifiques de niveau recherche, publiés ou non, émanant des établissements d'enseignement et de recherche français ou étrangers, des laboratoires publics ou privés. 


\title{
Lewis Acid and/or Lewis Base catalyzed [3+2] cycloaddition reaction: Synthesis of pyrazoles and pyrazolines
}

\author{
Palakodety Radha Krishna* and E. Raja Sekhar \\ D-206/B, Discovery Laboratory, Organic Chemistry Division-III \\ Indian Institute of Chemical Technology, Hyderabad-500 007, India
}

\begin{abstract}
A facile, 1,3-dipolar cycloaddition of ethyl diazoacetate (EDA) with various activated olefins including Baylis-Hillman adducts, activated and simple alkynes to afford 3,5-disubstituted pyrazolines and pyrazoles respectively in moderate to good yields, in high regioselective manner in the presence of Indium chloride and/or DABCO is reported. All the reactions were carried out under no strong bases/acids, solvent free conditions and at ambient temperature to afford the heterocyclic compounds.

Keywords: Ethyl diazoacetate, DABCO, Indium trichloride, activated olefins, BaylisHillman adducts, pyrazolines, pyrazoles.
\end{abstract}

Formation of heterocycles or carbocyclic five membered ring systems continue to be attractive for the synthesis of a variety of bioactive compounds. ${ }^{1}$ The most accessible route is either a) cyclization, which proceeds stepwise through one or more intermediates involving the expulsion of a small molecule such as an alcohol or water or b) cycloaddition, which proceed via no distinct intermediate but the bond formation may be asynchronous. Alternatively, [3+2] cycloaddition reaction strategy to form five membered ring systems through the reaction partners of 1,3-dipoles and dipolarophiles is an attractive protocol. According to FMO theory, the reaction to take place is a certain similarity of the interacting HOMO and LUMO orbitals depending on the relative orbital energies of both the dipolarophile and diploe. Electron withdrawing groups on the dipolarophile normally favor an interaction of the LUMO of the dipolarophile (electron poor olefin/alkyne) with HOMO of the diploe that leads to the formation of the new bonds, whereas electron donating groups on the dipolarophile normally favor the inverse of this reaction. ${ }^{2}$ In continuation of our efforts in the development of various aspects of Baylis-Hillman reaction, ${ }^{3}$ and utilityt of the adducts therof in the organic synthesis, ${ }^{4}$ herein we report the use of Baylis-Hillman adducts for $\mathrm{C}-\mathrm{N}$ bond formation ${ }^{5}$ to result in the heterocyclic ring formation affording corresponding pyrazolines (Scheme 1).

Scheme 1. Cycloaddition between various olefins and ethyl diazoacetate.

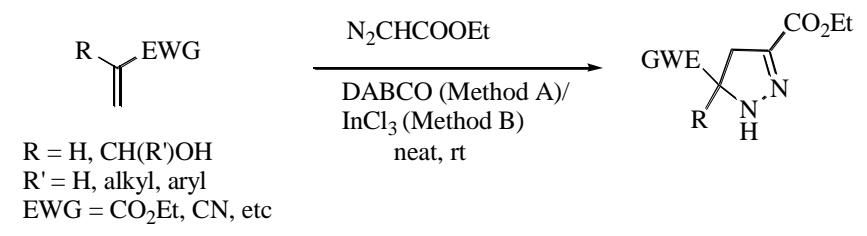

Pyrazoles $^{6}$ and pyrazolines ${ }^{7}$ derivatives are widely useful in agrochemistry as insecticides and in pharmaceuticals for varied applications. In general pyrazolines has been synthesized ${ }^{8}$ by cycloaddition of nitrile imines, ${ }^{9}$ 1,2-disubstituted (-COOR) alkene, ${ }^{10}$

*Author for Correspondence; Tel. No. +91-40-27160123, Ext. 2651; Fax: +91-4027160387: Email: prkgenius@iict.res.in 
azides. ${ }^{11}$ Interestingly, it may be noted that Baylis-Hillman adducts were less studied as substrates in cycloaddition reactions. ${ }^{12}$ Towards this endeavor, here in, we report our results on the cycloaddition of various types of Baylis-Hillman adducts as dipolarophiles with Ethyl diazoacetate (dipole) including simple acrylates to afford corresponding pyrazolines, as well as the synthesis pyrazoles from activated and simple alkynes as dipolarophiles.

The initial [3+2] cycloaddition reaction was conducted between ethyl acrylate 1 and ethyl diazoacetate (EDA) to afford 1a as the product. During the study, we found that $\mathrm{DABCO} / \mathrm{InCl}_{3}$ effectively catalyzes pyrazoline formation from simple Michael acceptor/electron poor olefin (ethyl acrylate) and EDA in 97 and 80\% yield respectively in $2 \mathrm{~h}$ at ambient temperature. For this protocol various solvents were examined and the maximum yield was obtained under neat conditions in shorter time scales. Subsequent to these preliminary investigations, the effects of different Lewis acids/and bases for the [3+2] cycloaddition reaction were examined (entries 1-11, Table 1).

\begin{tabular}{|c|c|c|c|c|}
\hline Entry & Lewis Acid/Lewis Base & Solvent & Time [h] & Product $(\%)^{\mathrm{ab}}$ \\
\hline 1 & DABCO & THF & 24 & 0 \\
\hline 2 & DABCO & DCM & 24 & 25 \\
\hline 3 & DABCO & DMF & 10 & 82 \\
\hline 4 & DABCO & Dioxane $\mathrm{H}_{2} \mathrm{O}$ & 6 & 90 \\
\hline $5^{\mathrm{c}}$ & $\overline{\mathrm{DABCO}}$ & neat & 2 & 97 \\
\hline 6 & DBU & neat & 2 & 0 \\
\hline 7 & Urotropine & neat & 4 & 89 \\
\hline 8 & NMM & neat & 5 & 83 \\
\hline 9 & $\mathrm{BF}_{3} \cdot \mathrm{OEt}_{2}$ & neat & 4 & 45 \\
\hline 10 & $\mathrm{FeCl}_{3}$ & neat & 5 & 61 \\
\hline $11^{\mathrm{c}}$ & $\mathrm{InCl}_{3}$ & neat & 2 & 80 \\
\hline 12 & no catalyst & neat & 24 & 0 \\
\hline
\end{tabular}

\footnotetext{
${ }^{a}$ Determined by ${ }^{1} \mathrm{H}$ NMR of pure compound. ${ }^{b}$ Isolated yields after column chromatography

${ }^{\mathrm{c}}$ The best yield under these conditions.
}

Among the various Lewis bases that were examined, DABCO (Table 1, entry 1), provided the desired product (1a, Table 2) in the best yield under solvent free conditions (neat) when compared to NMM (Table 1, entry 4) and Urotropine (Table 1, entry 3). Surprisingly DBU (table 1, entry 2) did not catalyze the [3+2] cycloaddition reaction. However, Indium chloride (Table 1, entry 7), among the Lewis acids catalyzed the reaction to afford the desired product $\mathbf{1 a}$ in best yield under solvent free conditions when compared to other Lewis acids such as $\mathrm{BF}_{3} . \mathrm{OEt}_{2}$ and $\mathrm{FeCl}_{3}$ (entries 5-6, Table 1). 
Amongst the two $\mathrm{DABCO}$ and $\mathrm{InCl}_{3}$, the reaction was more facile with $\mathrm{DABCO}$ to afford products in good yields and in shorter time. As illustrated (entries 5-7, Table 1) the product yield increased with decreasing acidity of the Lewis acids.

Table 2. Cycloaddition between electron poor olefins and ethyldiazoacetate under methods A/B

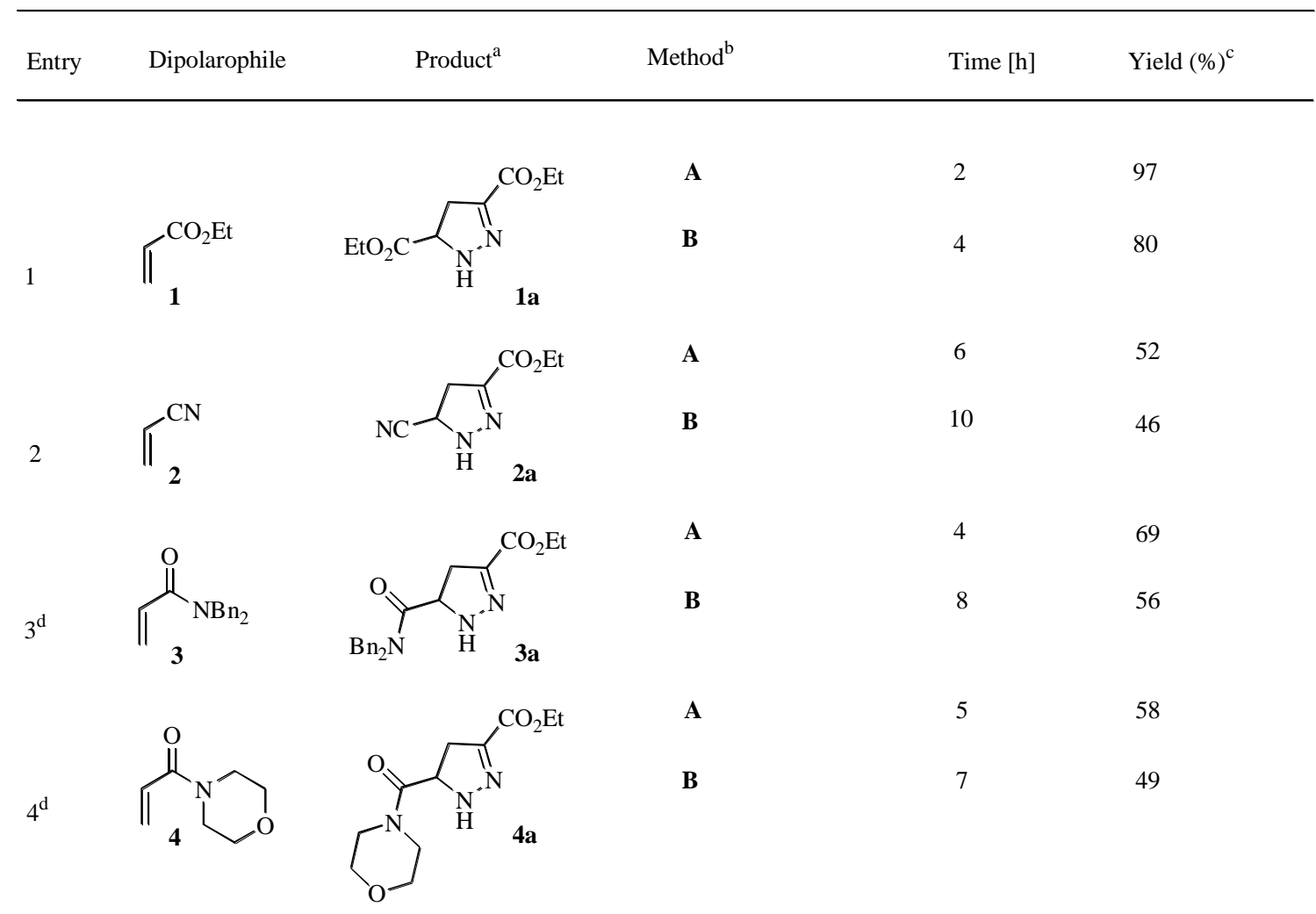

\footnotetext{
${ }^{\mathrm{a}}$ All the products were charecterized their spectral data.

${ }^{\mathrm{b}}$ Method A: Olefin (1.0 eq.), EDA (1.0 eq.), DABCO (0.1 eq.) were stirred at ambient temperature for specified hours to afford the products after purification; Method B: Olefin (1.0 eq.), $\mathrm{EDA}\left(1.0\right.$ eq.), $\mathrm{InCl}_{3}(0.1$ eq.) were stirred at ambient temperature until the completion of the reaction.

c Isolated yields.

${ }^{\mathbf{d}}$ For these substates, olefin and EDA were taken in 2:1 ratio with the catalyst (0.1 eq.).
}

Pyrazoline 1a was characterized through its spectral data. For instance, its ${ }^{1} \mathrm{H}$ NMR spectrum revealed characteristic $\mathrm{H}-5$ at $\delta 4.40(\mathrm{dd}, J=6.0,12.8 \mathrm{~Hz})$ and $\mathrm{H}-4$ at $\delta 3.30$ (ddd, $J=1.5,5.8,18.8 \mathrm{~Hz}$ ) and $\delta 3.17(\mathrm{dd}, J=12.6,18.8 \mathrm{~Hz}$ ). IR spectrum displayed the charecteristic $1571 \mathrm{~cm}^{-1}$ for $\mathrm{C}-\mathrm{N}$ stretching frequencies, apart from frequencies due to the other functional groups present.

Later, we applied this cycloaddition reaction under both Method A and Method B conditions to several simple electron poor olefins such as acrylonitrile 2 (entry 2, Table 2), N,N-dibenzyl acrylamide 3 (entry 3, Table 2), and 4-acryloylmorpholine 4 (entry 4, Table 2) with EDA to afford the corresponding pyrazolines (2a-4a) in good yields (Table 2).

The scope of the cycloaddition was further investigated with Baylis-Hillman adducts and EDA (Table 3). For instance, adduct 5 (Table 3, entry 1) underwent cycloaddition with EDA in the presence of DABCO (method A) as well as with $\mathrm{InCl}_{3}$ (method $\mathrm{B}$ ) to afford 
corresponding pyrazoline 5a in 75 and $60 \%$ yields respectively under solvent free conditions (neat). Later other adducts, such as the one containing an electron withdrawing group ( $p-\mathrm{NO}_{2}$ group) on the benzene ring (entry 2, Table 3), yielded the desired product 6a in excellent yield (95\%) while the adduct possessing the $o-\mathrm{NO}_{2}$ group (entry 3, Table 3 ) led to comparatively less yield of the corresponding product 7a (86\%) under similar reaction conditions. Adduct 8 possessing a long carbon chain (entry 4, Table 3) and a simple adduct 9 with least number of carbon atoms (entry 5, Table 3) also provided the corresponding pyrazolines 8a and 9a in good yields. All the products were identified by their spectral data (Please see reference section).

Table 3. Cycloaddition between various Baylis-Hillman adducts (dipolarophile) and ethyldiazoacetate under methods A/B

\footnotetext{
${ }^{a}$ All the products were charecterized their spectral data.

${ }^{\mathrm{b}}$ Method A: Olefin (1.0 eq.), EDA (1.0 eq.), DABCO (0.1 eq.) were stirred at ambient temperature for specified hours to afford the products after purification; Method B: Olefin (1.0 eq.), $\mathrm{EDA}\left(1.0\right.$ eq.), $\mathrm{InCl}_{3}(0.1 \mathrm{eq}$.) were stirred at ambient temperature until the completion of the reaction.

c Isolated yields.
}

Interestingly, when [3+2] cycloaddition reaction was performed on a simple alkyne such as phenylacetylene $\mathbf{1 0}$ and electron poor alkyne such as ethyl propiolate $\mathbf{1 1}$ gave the corresponding pyrazoles 10a and 11a in good yields. The earlier reported method did not give the products under the Lewis acid in under aqueous conditions. ${ }^{13}$ Herein, while $\mathbf{1 0}$ gave 10a under both the reaction conditions (Method $\mathrm{A}$ and $\mathrm{B}$, Scheme 2, route a) in comparable yields, 11 gave the desired product 11a (Scheme 2, route b), under Method B conditions alone. Thus, with DABCO (Method A) a facile self coupling led to the undesired diethyl-2E-en-4-yn-1,6-dioate ${ }^{14}$ as the only product (Scheme 2, route b). But the same reaction in the presence of Lewis acid $\left(\mathrm{InCl}_{3}\right)$, cycloaddition product was obtained exclusively (Scheme 2, route b). Both 10a and 11a were characterized by their spectral data. For instance, ${ }^{1} \mathrm{H}$ NMR spectrum of $\mathbf{1 0 a}$ and $11 \mathrm{a}$ revealed the lone aromatic proton at $\delta 7.08$ and at $\delta 7.27$ respectively. The spectral data of 10a and 11a matched 
with reported values. ${ }^{6,14}$ Thus, this result conclusively proves the regioselectivity of [3+2] cycloaddition reaction. The same analogy was extending to assign the regioselectivity of all the pyrazolines (1a-9a) as well.

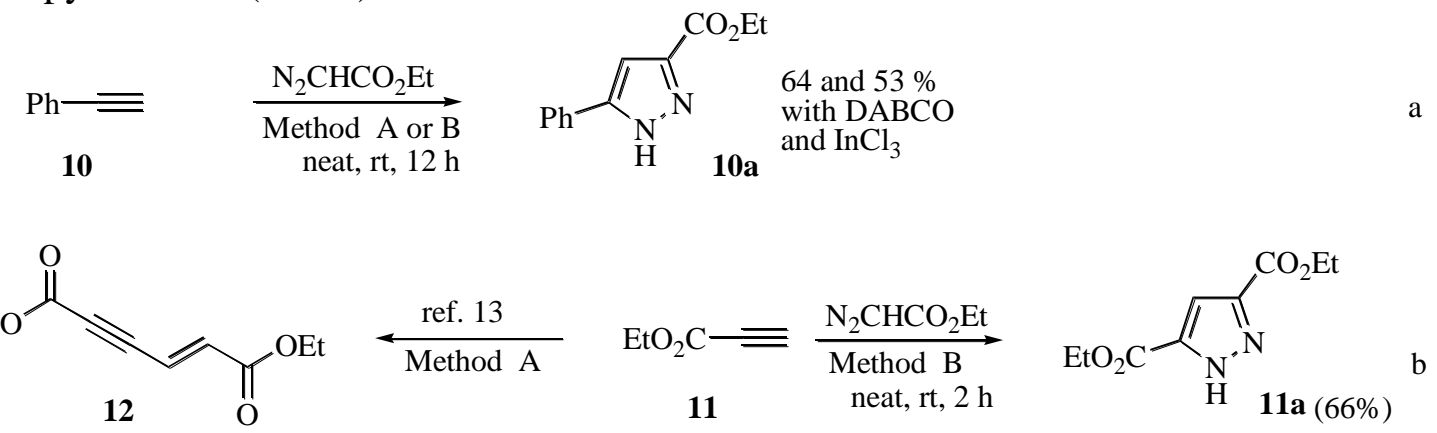

Scheme 2. Reaction of phenylacetylene and ethylpropiolate with ethyldiazoacetate under method A and/or B conditions.

Thus, while the Lewis acid catalyzed cycloaddition followed the standard reaction pathway of activating dipolarophile ${ }^{15}$ by lowering the energy of the LUMO that consequently acts with HOMO of diploe in affording the products, Lewis base promoted activation presumably may have taken the course of forming the Huisgen zwitterions upon addition on thei ethyl acrylate or EDA which subsquently reacts with its counterpart to result in products.

In conclusion, a simple, general one-pot protocol for the synthesis of heterocyclic 3,5disubstituted pyrazolines and pyrazoles was developed from different type of electron poor olefins/alkyne including Baylis-Hillman adducts and EDA under mild conditions in good to excellent yields. Alkynes also provided the desired products. On the other hand, variety of Lewis bases such as Urotropine, NMM, DBU and Lewis acids like $\mathrm{BF}_{3} . \mathrm{OEt}_{2}$, $\mathrm{FeCl}_{3}$ apart from $\mathrm{DABCO}$ and $\mathrm{InCl}_{3}$ were also screened during the standerdization of cycloaddition reaction.

Acknowledgement. The authors are thankful to the Department of Science and Technology, New Delhi, India, for financial assistance of the Grants-in-Aid project under SERC (No.SR/S1/OC-59/2006). One of the authors (E. R. S.) thanks the CSIR, New Delhi, India, for financial support in the form of a fellowship.

\section{References}

1. Synthetic Applications of 1,3-Dipolar Cycloaddition Chemistry Toward Heterocycles and Natural Products (Eds: A. Padwa, W. H. Pearson), Wiley, Hoboken, 2003.

2. Huisgen, R.; Grashey, R.; Sauer, J. In: Chemistry of alkenes, Interscience, New York, 1964, 806.

3. a) Radha Krishna, P.; Kannan, V.; Ilangovan, A.; Sharma, G. V. M. Tetrahedron: Asymm. 2001, 12, 829-837; b) Radha Krishna, P.; Raja Sekhar, E.; Kannan, V. Tetrahedron Lett. 2003, 44, 4973-4975; c) Radha Krishna, P.; Kannan, V.; Sharma, G. V. M. Synth. Commun. 2004, 34, 55-64; d) Radha Krishna, P.; 
Manjuvani, A.; Kannan, V.; Sharma, G. V. M. Tetrahedron Lett. 2004, 45, 1183 1185; e) Radha Krishna, P.; Raja Sekhar, E.; Kannan, V. Synthesis 2004, 857860; f) Radha Krishna, P.; Kannan, V.; Narasimha Reddy, P. V. Adv. Synth. Cat. 2004, 346, 603-606.

4. a) Radha Krishna, P.; Kannan, V.; Sharma, G. V. M. Synth. Commun. 2004, 34, 55. b) Radha Krishna, P.; Narsingam, M.; Kannan, V. Tetrahedron Lett. 2004, 45, 4773-4775. c) Radha Krishna, P.; Narsingam, M.; Srinivas Reddy, P.; Srinivasulu, G.; Kunwar, A. C. Tetrahedron Lett. 2005, 46, 8885. d) Radha Krishna, P.; Narsingam, M. J. Comb. Chem. 2007, 9, 62.

5. Nair, V.; Menon, R. S.; Sreekanth, A. R.; Abhilash, N.; Biju, A. T. Acc. Chem. Res. 2006, 39, 520 - 530.

6. See synthesis and biological activity of pyrazoles: Qi, X.; Ready, J. M. Angew. Chem. Int. Ed. 2007, 46, 3242-3244 and references cited therein.

7. See for information of Pyrazolines: Lévai, A. Chemistry of Heterocyclic Compounds, 1997, 33, 647-659.

8. (a) Eleguero, J. in Comprehensive Heterocyclic Chemistry, Vol. 5 (Eds.: A. R. Katritzky, C. W. Rees, K. T. Potts), Pergamon, Oxford, 1984, p. 167; (b) Eleguero, J. In Comprehensive Heterocyclic Chemistry II; Katritzky, A. R.; Rees, C. W.; Scriven, E. F., Eds.; Pergamon Press: Oxford, 1996; Vol. 3, pp. 1-75.

9. Kanemasa, S.; Kobayashi, S. Bull. Chem. Soc. Jpn., 1993, 66, 2685-2693.

10. Yamauchi, M.; Yajima, M. Chem. Pharm. Bull. 2001, 49, 1638-1639.

11. Yadav, J. S.; Subba Reddy, B. V.; Geetha, V. Synlett 2002, 513-515.

12. Basavaiah, D.; Jaganmohan Rao, A.; Satyanarayana, T. Chem. Rev. 2003, 103, 811-891.

13. Jiang, N.; Li, C. -J. Chem. Commun. 2004, 394-395.

14. Ramachandran, P. V.; Rudd, M. T.; Reddy, M. V. R. Tetrahedron Lett. 2005, 46, 2547.

15. Gothelf, K. V.; Jorgensen, K. A. Chem. Rev. 1998, 98, 863.

16. General experimental procedure: Method A: Activated olefin, ethyl acrylate 1 $(0.1 \mathrm{~g}, 1 \mathrm{mmol})$, ethyl diazoacetate $(57 \mathrm{mg}, 0.5 \mathrm{mmol})$ and DABCO (11 mg, 0.1 mmol) were placed in a dry round bottom flask and the reaction mixture was allowed to stir for $2 \mathrm{~h}$ under neat at ambient temperature until the completion of reaction (tlc) and the reaction mixture was absorbed directly and purified by column chromatography (Silica gel, 60-120 mesh, EtOAC:hexane, 2:8) to afford pure 1a in 97\% yield. Method B: A mixture of activated olefin, ethyl acrylate 1 $(0.1 \mathrm{~g}, 1 \mathrm{mmol})$, ethyl diazoacetate $(57 \mathrm{mg}, 0.5 \mathrm{mmol})$ and $\mathrm{InCl}_{3}(22 \mathrm{mg}, 0.1$ mmol) were placed and stirred under neat at ambient temperature for $4 \mathrm{~h}$ following absorption of reaction mixture, purified by column chromatography to afford $1 \mathrm{a}$ in $80 \%$ yield.

17. Spectral data for selected compounds: 1a. Yellow oil; ${ }^{1} \mathrm{H}$ NMR $(200 \mathrm{MHz}$, $\left.\mathrm{CDCl}_{3}\right): \delta=6.72($ br s, $1 \mathrm{H}, \mathrm{NH}), 4.40(\mathrm{dd}, 1 \mathrm{H}, J=6.0,12.8 \mathrm{~Hz}, \mathrm{H}-5), 4.34-4.15$ $\left(\mathrm{m}, 4 \mathrm{H}, 2 \mathrm{x}-\mathrm{OCH}_{2}\right), 3.30$ (ddd, $\left.1 \mathrm{H}, J=1.5,5.8,18.8 \mathrm{~Hz}, \mathrm{H}-4\right), 3.17$ (dd, $1 \mathrm{H}, J=$ 12.6, $\left.18.8 \mathrm{~Hz}, \mathrm{H}-4^{\prime}\right), 1.50-1.20\left(\mathrm{~m}, 6 \mathrm{H}, 2 \mathrm{x} \mathrm{CH}_{3}\right) ;{ }^{13} \mathrm{C} \mathrm{NMR}\left(75 \mathrm{MHz}, \mathrm{CDCl}_{3}\right): \delta$ 171.5, 142.6, 111.2, 61.9, 61.4 (2C), 34.6, 14.1 (2C); IR (neat): 3356, 2984, 1734, 1571, $1250 \mathrm{~cm}^{-1}$; ES-MS: $\mathrm{m} / z=214\left(\mathrm{M}^{+}\right)$; Anal. calcd. for $\mathrm{C}_{9} \mathrm{H}_{14} \mathrm{~N}_{2} \mathrm{O}_{4}$ : C, 50.46; $\mathrm{H}, 6.59 \%$; found C, 50.41; H, 6.62\%. 3a. Syrup; ${ }^{1} \mathrm{H}$ NMR $\left(200 \mathrm{MHz}, \mathrm{CDCl}_{3}\right): \delta=$ 
7.40-7.10 (m, 10H, Ar-H), 6.40 (br. s, $1 \mathrm{H}, \mathrm{NH}), 4.84$ (d, J=5.3 Hz, 2H, $-\mathrm{CH}_{2} \mathrm{Ph}$ ), $4.56\left(\mathrm{~d}, J=6.4 \mathrm{~Hz}, 2 \mathrm{H},-\mathrm{CH}_{2} \mathrm{Ph}\right), 4.22(\mathrm{dd}, 1 \mathrm{H}, J=5.2,12.4 \mathrm{~Hz}, \mathrm{H}-5), 4.20(\mathrm{q}, J$ $\left.=6.7 \mathrm{~Hz}, 2 \mathrm{H},-\mathrm{OCH}_{2}\right), 3.49-3.25\left(\mathrm{~m}, 2 \mathrm{H}, \mathrm{CH}_{2}\right), 1.29\left(\mathrm{t}, J=6.3 \mathrm{~Hz}, 3 \mathrm{H}, \mathrm{CH}_{3}\right) ;{ }^{13} \mathrm{C}$ NMR $\left(75 \mathrm{MHz}, \mathrm{CDCl}_{3}\right): \delta 162.7,146.6,136.3,128.0,127.8,127.5,127.0,126.8$, 61.3, 59.3, 50.2, 47.7, 37.1, 13.5; IR (neat): 3348, 2925, 1735, 1622, 1449, 1239 $\mathrm{cm}^{-1}$; ESI-MS: $\mathrm{m} / z=338\left(\mathrm{M}^{+}+1\right)$; Anal. Calcd for $\mathrm{C}_{20} \mathrm{H}_{23} \mathrm{~N}_{3} \mathrm{O}_{2}: \mathrm{C}, 71.19 ; \mathrm{H}$, 6.87\%; Found: C, 71.13; H, 6.93\%. 4a. Syrup; ${ }^{1} \mathrm{H}$ NMR $\left(200 \mathrm{MHz}, \mathrm{CDCl}_{3}\right): \delta=$ 6.81 (br s, 1H, NH), 4.51 (t, 1H, $J=5.2 \mathrm{~Hz}, \mathrm{H}-5), 4.25$ (q, 2H, $J=7.4 \mathrm{~Hz}, \mathrm{OCH}_{2}$ ), 3.70-3.54 (m, 4H, $\left.\mathrm{CH}_{2}\right), 3.51-3.44\left(\mathrm{~m}, 2 \mathrm{H}, \mathrm{CH}_{2}\right), 3.28(\mathrm{dd}, 1 \mathrm{H}, J=12.6,17.0 \mathrm{~Hz}$, $\left.\mathrm{CH}_{2}\right), 3.01\left(\mathrm{dd}, 1 \mathrm{H}, J=5.2,17.0 \mathrm{~Hz}, \mathrm{CH}_{2}\right), 1.40-1.18\left(\mathrm{~m}, 3 \mathrm{H}, \mathrm{CH}_{3}\right)$. ESI-MS: $\mathrm{m} / \mathrm{z}$ $=256\left[\mathrm{M}^{+}+1\right]$. Anal. Calcd for $\mathrm{C}_{11} \mathrm{H}_{17} \mathrm{~N}_{3} \mathrm{O}_{4}: \mathrm{C}, 51.76 ; \mathrm{H}, 6.71 \%$; Found: $\mathrm{C}, 51.71$; $\mathrm{H}, 6.78 \%$. 5a. Syrup; ${ }^{1} \mathrm{H}$ NMR $\left(200 \mathrm{MHz}, \mathrm{CDCl}_{3}\right): \delta=7.31(\mathrm{~s}, 5 \mathrm{H}, \mathrm{Ar}-\mathrm{H}), 6.81$ (br, s, 1H, NH), 4.99 (s, 1H, -CHOH), $4.30-4.10\left(\mathrm{~m}, 4 \mathrm{H}, 2\right.$ x $\left.\mathrm{OCH}_{2}\right), 3.18(\mathrm{~d}, J=$ $2.5 \mathrm{~Hz}, 2 \mathrm{H}, \mathrm{H}-4), 1.40-1.15\left(\mathrm{~m}, 6 \mathrm{H}, 2 \mathrm{XCH}_{3}\right) ;{ }^{13} \mathrm{C} \mathrm{NMR}\left(75 \mathrm{MHz}, \mathrm{CDCl}_{3}\right): \delta$ $143.2,137.3,126.6,127.9,75.1,61.8,60.8,35.3,29.2,13.7,13.4 ; \quad I R$ (neat): 3448, 2984, 1731, 1638, $1253 \mathrm{~cm}^{-1}$; ESI-MS: $\mathrm{m} / \mathrm{z}=343\left[\mathrm{M}^{+}+23\right]$; Anal. Calcd for $\mathrm{C}_{16} \mathrm{H}_{20} \mathrm{~N}_{2} \mathrm{O}_{5}$ : C, 59.99; H, 6.29\%; Found: C, 60.04; H, 6.22\%. 7a. Syrup; ${ }^{1} \mathrm{H}$ NMR $\left(200 \mathrm{MHz}, \mathrm{CDCl}_{3}\right): \delta=7.92(\mathrm{~d}, J=7.8 \mathrm{~Hz}, 2 \mathrm{H}, \mathrm{Ar}-\mathrm{H}), 7.61(\mathrm{t}, J=8.6 \mathrm{~Hz}, 1 \mathrm{H}$ Ar-H), $7.51(\mathrm{t}, J=7.8 \mathrm{~Hz}, 1 \mathrm{H}, \mathrm{Ar}-\mathrm{H}), 7.10(\mathrm{~s}, \mathrm{NH}), 5.81(\mathrm{~s}, 1 \mathrm{H},-\mathrm{CHOH}), 4.19(\mathrm{~m}$, $\left.4 \mathrm{H}, 2 \mathrm{XCH}_{2}\right), 3.10(\mathrm{~d}, J=3.4 \mathrm{~Hz}, 2 \mathrm{H}, \mathrm{H}-4), 1.22\left(\mathrm{~m}, 6 \mathrm{H}, 2 \mathrm{XCH}_{3}\right) ;{ }^{13} \mathrm{C} \mathrm{NMR}(75$ $\left.\mathrm{MHz}, \mathrm{CDCl}_{3}\right): \delta 172.0,148.7,143.7,133.5,130.2,129.2,124.3,68.9,62.8,61.4$, 61.3, 59.8, 14.1, 13.8; IR (neat): 3449, 2924, 1727, 1636, $1256 \mathrm{~cm}^{-1}$; ESI-MS: $\mathrm{m} / \mathrm{z}$ $=388\left[\mathrm{M}^{+}+23\right]$. Anal. Calcd for $\mathrm{C}_{16} \mathrm{H}_{19} \mathrm{~N}_{3} \mathrm{O}_{7}: \mathrm{C}, 52.60 ; \mathrm{H}, 5.24 \%$; Found: $\mathrm{C}$, 52.65; H, 5.22\%. 8a. Syrup; ${ }^{1} \mathrm{H}$ NMR $\left(300 \mathrm{MHz}, \mathrm{CDCl}_{3}\right): \delta=6.63$ (br s, $1 \mathrm{H}$, $\mathrm{NH}), 5.25(\mathrm{t}, J=7.3 \mathrm{~Hz}, 1 \mathrm{H},-\mathrm{CH}-\mathrm{OH}), 4.31-4.02\left(\mathrm{~m}, 4 \mathrm{H}, 2 \mathrm{XCH}_{2}\right), 3.41-2.98$ $(\mathrm{m}, 2 \mathrm{H}, \mathrm{H}-4), 1.45-1.23(\mathrm{~m}, 12 \mathrm{H}), 0.92-0.85\left(\mathrm{br}, \mathrm{t}, 3 \mathrm{H}, \mathrm{CH}_{3}\right) ;{ }^{13} \mathrm{C} \mathrm{NMR}$ $\left(200 \mathrm{MHz}, \mathrm{CDCl}_{3}\right): \delta 171.1,161.8,138.3,64.3,61.5,36.8,34.6,31.2,29.0,25.0$, 22.2, 13.7; IR (neat): 3354, 2980, 2934, 2867, 1739, 1703, $1252 \mathrm{~cm}^{-1}$; ESI-MS: $m / z=296\left(\mathrm{M}^{+}+23\right)$. 9a. Syrup; ${ }^{1} \mathrm{H}$ NMR $\left(200 \mathrm{MHz}, \mathrm{CDCl}_{3}\right): \delta=4.29-4.14(\mathrm{~m}$, $\left.4 \mathrm{H}, \mathrm{CH}_{2}\right), 3.70\left(\mathrm{dd}, 2 \mathrm{H}, J=10.5,26.2 \mathrm{~Hz}, \mathrm{CH}_{2} \mathrm{OH}\right), 3.03(\mathrm{dd}, 2 \mathrm{H}, J=17.2,60.8$ $\mathrm{Hz}, \mathrm{H}-4), 1.32$ (hextet, $\left.6 \mathrm{H}, J=4.5,7.5,11.2 \mathrm{~Hz}, 2 \times \mathrm{CH}_{3}\right) .{ }^{13} \mathrm{C} \mathrm{NMR}(75 \mathrm{MHz}$, $\left.\mathrm{CDCl}_{3}\right): \delta=172.1,161.7,142.9,73.8,70.3,65.1,62.8,62.2,37.2$, 14.0. ESI-MS: $245\left[\mathrm{M}^{+}+1\right]$. Anal. Calcd for $\mathrm{C}_{10} \mathrm{H}_{16} \mathrm{~N}_{2} \mathrm{O}_{5}: \mathrm{C}, 49.18 ; \mathrm{H}, 6.60 \%$; Found: 49.24; $\mathrm{H}$, 6.56\%. 10a. Syrup; ${ }^{1} \mathrm{H}$ NMR (300 MHz, $\left.\mathrm{CDCl}_{3}\right): \delta=7.76(\mathrm{~d}, 2 \mathrm{H}, J=6.79 \mathrm{~Hz}$, Ar-H), 7.43-7.30 (m, 3H, Ar-H), 7.08 (s, 1H, Ar-H), 4.37 (q, 2H, $J=6.79 \mathrm{~Hz}$, $\left.\mathrm{CH}_{2}\right), 1.41\left(\mathrm{t}, 3 \mathrm{H}, J=6.79 \mathrm{~Hz}, \mathrm{CH}_{3}\right) .{ }^{13} \mathrm{C} \mathrm{NMR}\left(75 \mathrm{MHz}, \mathrm{CDCl}_{3}\right): \delta=128.9$, 128.5, 127.7, 125.7, 113.9, 105.6, 61.3, 14.2. IR (neat): 2924, 1724, $1244 \mathrm{~cm}^{-1}$. ESI-MS: $217\left[\mathrm{M}^{+}+1\right]$. Anal. Calcd for $\mathrm{C}_{12} \mathrm{H}_{12} \mathrm{~N}_{2} \mathrm{O}_{2}$ : C, 66.65; H, 5.59\%; Found: C, 66.69; H, 5.54\%. 11a. Syrup; ${ }^{1} \mathrm{H}$ NMR $\left(300 \mathrm{MHz}, \mathrm{CDCl}_{3}\right): \delta=12.9$ (br s, $1 \mathrm{H}$, $\mathrm{NH}), 7.27$ (s, 1H, Ar-H), 4.37 (q, 2H, J = 6.79 Hz, CH2), 1.38 (t, 3H, J = 6.79 Hz, $\mathrm{CH} 3) .{ }^{13} \mathrm{C} \mathrm{NMR}\left(75 \mathrm{MHz}, \mathrm{CDCl}_{3}\right): \delta=160.3,111.2,61.6,14.1$. IR (neat): 3145 , 2984, 1729, $1250 \mathrm{~cm}^{-1}$. ESI-MS: $213\left[\mathrm{M}^{+}+1\right]$. Anal. Calcd for $\mathrm{C}_{9} \mathrm{H}_{12} \mathrm{~N}_{2} \mathrm{O}_{4}: \mathrm{C}$, 50.94; H, 5.70\%; Found: C, 50.99; H, 5.67\%. 